\title{
United States - Anti-Dumping Measures on Oil Country Tubular Goods (OCTG) from Mexico: a legal-economic assessment of sunset reviews
}

\author{
CHAD P. BOWN \\ Department of Economics and International Business School, MS 021, Brandeis University, PO Box 549110, \\ Waltham, MA, 02454-9110 USA \\ Email: cbown@brandeis.edu,web: http://www.brandeis.edu/ cbown/ \\ JASPER WAUTERS \\ White \& Case International Trade (Geneva), 82 Rue de Lausanne, 1202 Geneva, Switzerland \\ Email: jwauters@whitecase.com
}

\begin{abstract}
This paper reviews the WTO Appellate Body Report on United States - Anti-Dumping Measures on Oil Country Tubular Goods (OCTG) from Mexico (WT/DS282/AB/R 2 November 2005). This dispute concerns the disciplines imposed by the Anti-Dumping Agreement on WTO Members seeking to extend their anti-dumping measures beyond the original five-year period through a so-called sunset review. Our analysis focuses on the Appellate Body's finding in this case that no causation analysis is required in sunset reviews, and addresses the AB's approach towards the legal instrument that provides for the US policy in terms of sunset reviews, the Sunset Policy Bulletin. We conclude that the Anti-Dumping Agreement, as interpreted by the Appellate Body in this and other similar cases, imposes only minimal disciplines of a general nature on Members wishing to extend the anti-dumping measure beyond its original five-year period. We argue that the 'textual' argument relied on to support this deferential approach is weak and has resulted in undermining the practical effect of, what was considered to be, one of the major achievements of the Uruguay Round Anti-Dumping Agreement: limiting the life span of an anti-dumping measure to five years. From an economic perspective, Panels and the Appellate Body are simply debating the wrong type of questions. The prospective nature required by a sunset review analysis raises questions such as why exporters engaged in dumping in the first place, and what the conditions of the industry were so that the dumped imports caused injury. At the moment, sunset reviews
\end{abstract}

\footnotetext{
This paper reviews the WTO Appellate Body Report, United States - Anti-Dumping Measures on Oil Country Tubular Goods (OCTG) from Mexico (WT/DS282/AB/R 2 November 2005). Thanks to William Davey and ALI conference participants in Geneva for useful comments on an earlier draft. The views expressed in this paper are those of the authors and should not be attributed to White and Case or any of its clients. All remaining errors are our own.
} 
seem adrift as panels and the Appellate Body fail to give guidance to Members on how to do a more economically sound and informed review.

\section{Introduction}

This dispute concerns the disciplines imposed by the Anti-dumping (AD) Agreement on WTO Members seeking to extend their anti-dumping measures beyond the original five-year period. In essence, this dispute examines the question of whether the AD Agreement actually imposes certain substantive disciplines on authorities when conducting such sunset reviews.

By way of background, the $\mathrm{AD}$ Agreement provides for termination of $\mathrm{AD}$ duties after five years. AD duties can, in principle, remain in place for a period longer than five years. In other words, termination of the duty is the rule, and its continuation is the exception. ${ }^{1}$ How much longer duties may remain in place depends on the outcome of successive reviews, called 'sunset reviews', in which authorities examine whether dumping and injury are likely to continue or recur in case the duty is terminated. The terms continuation and recurrence refer to two different factual situations: the first term presupposes that dumping and/or injury have not ceased to exist during the period of imposition of AD duties; the latter presupposes that the opposite has happened during the same period. The methodology used to demonstrate the likelihood of continuation or recurrence is not prejudged by the Article 11.3 AD Agreement, which is the only provision in the AD Agreement that specifically deals with such sunset reviews.

Mexico claimed that the way the US conducts such sunset reviews is inconsistent with the AD Agreement. Its complaint related to both US laws and regulations concerning sunset reviews and the specific application of such laws in the sunset review of an anti-dumping duty order imposed by the US on imports of oil-country tubular goods (OCTG) ${ }^{2}$ from Mexico and other sources.

\section{The facts}

In August 1995, the US issued an anti-dumping duty order on OCTG from a number of countries including Mexico. The US Department of Commerce (USDOC), the authority responsible for determining the existence and amount of dumping in the US, calculated a dumping margin for the largest Mexican producer (TAMSA), and assigned margins based on this producer's rate to the other, non-investigated producers, such as Hylsa. Following the imposition of the anti-dumping duty, TAMSA stopped exporting to the US and thus was no longer

1 Appellate Body Report, US-Carbon Steel, para. 88. The experience over the last ten years with sunset reviews has actually been that the extension of the $\mathrm{AD}$ measure is the rule rather than the exception.

2 Such goods are used mainly for oil exploration and mining purposes. 
dumping its products into the US. Yearly administrative reviews of the measure thus led to a zero dumping margin for TAMSA.

In the 'sunset review', USDOC and the US International Trade Commission (USITC), the US authority responsible for determining whether there is injury to the US domestic industry, examined whether termination of the duty on Mexican OCTG would be likely to lead to a recurrence or continuation of dumping and injury. Their conclusion was that it would. The likely dumping margin to prevail in case of termination of the duty was calculated to be $21.70 \%$, a figure that corresponds with the rate calculated in the original investigation, as amended.

As a result, instead of revoking the anti-dumping duty order on OCTG from Mexico, the anti-dumping measures were extended for another five-year period effective as of 25 July 2001.

\section{Mexico's claims}

Before the Panel, Mexico made a number of claims arguing that the US should have terminated the duty even before the sunset review in the course of one of the yearly administrative reviews. In the absence of dumping by the Mexican exporters, there was no need to maintain the duty 'in order to offset dumping'. In any case, according to Mexico, the duty should have been terminated at the end of the five-year period, and the US contrary affirmative determination of likelihood of dumping and injury recurring following expiry of the duty was flawed.

Mexico's claims related to the likelihood-of-dumping determination, as well as the standard for determining likelihood of injury in sunset reviews. With respect to the specific USITC determination of likely injury in the case of OCTG imports from Mexico, Mexico argued that the US failed to comply with a number of the disciplines set forth in Article $3 \mathrm{AD}$ Agreement on injury, which it considers also to apply in sunset reviews. ${ }^{3}$ In particular, Mexico alleged inter alia that the USITC did not examine all 15 factors of Article 3.4 AD, relied on a cumulative assessment of imports without legal basis and in a manner inconsistent with Article 3.3, and did not examine whether the likely injury would be caused by the dumped imports.

Against the background of this particular OCTG case, Mexico made a number of claims concerning the legal standards and requirements present in US law and US practice in respect of sunset reviews, which it considers to be inconsistent with the $\mathrm{AD}$ Agreement. In this respect, an important document challenged was the USDOC's Sunset Policy Bulletin in which this USDOC explains how it will determine the existence of a likelihood of dumping in sunset reviews.

3 According to Mexico, the definition of the term 'injury' in Article 3 and footnote 9 applies throughout AD Agreement and thus also in respect of a determination of likelihood of continuation or recurrence of injury under Article 11.3. 
Mexico argued that Section II.A.3 of the US Sunset Policy Bulletin ${ }^{4}$ (SPB) and USDOC 'practice' in the performance of sunset reviews are inconsistent, 'as such' with its obligations under Article 11.3. According to Mexico, it is clear from the SPB that the US authorities base their determinations on presumptions that dumping is likely to continue or recur in certain factual situations that are given decisive weight. The key elements in such factual scenarios are import volumes and dumping margins. If the situation described in any of the scenarios is met, likelihood will be found to exist without consideration of other relevant positive evidence. ${ }^{5}$ Mexico argued that, by basing its sunset determination on such assumptions, the US is not complying with the obligation of the AD Agreement to base a sunset review determination on facts and evidence, rather than assumptions.

\section{The United States response}

The United States was of the view that nothing in the Agreement requires a WTO Member to terminate an anti-dumping measure following a finding of no dumping in the course of one or more administrative reviews.

The United States disagreed as to the applicability in sunset reviews of the disciplines of Article $3 \mathrm{AD}$ Agreement relating to a determination of the existence of injury in original investigations. According to the US, a sunset review is concerned with the determination of the likelihood of recurrence or continuation of injury as a consequence of the termination of the measure, and because of this different nature and purpose, the disciplines of Article 3 do not apply. In the absence of a textual basis to import such disciplines into sunset reviews, the US argued that different questions warrant different methods of analysis and the

4 Section II.A. 3 of the SPB reads in relevant part as follows:

the Department normally will determine that revocation of an antidumping order or termination of a suspended dumping investigation is likely to lead to continuation or recurrence of dumping where-

(a) dumping continued at any level above de minimis after the issuance of the order or the suspension agreement, as applicable;

(b) imports of the subject merchandise ceased after issuance of the order or the suspension agreement, as applicable; or

(c) dumping was eliminated after the issuance of the order or the suspension agreement, as applicable, and import volumes for the subject merchandise declined significantly.

The Department recognizes that, in the context of a sunset review of a suspended investigation, the data relevant to the criteria under paragraphs (a) through (c), above, may not be conclusive with respect to likelihood. Therefore, the Department may be more likely to entertain good cause arguments under paragraph II.C in a sunset review of a suspended investigation.

5 This is what had occurred also in the sunset review concerning OCTG from Mexico. The USDOC concluded that there was a likelihood of dumping because the exports had stopped following the imposition of the antidumping order. A decline in import volume following the order is one of the factual scenarios which, according to the SPB, reveals a likelihood of dumping in the future as it allegedly shows that, without dumping, the exporter cannot sell its products in the US market. Mexico considered that such a presumption is inconsistent with the $\mathrm{AD}$ Agreement's requirements of making objective examinations based on positive evidence. 
consideration of different factors. According to the US, any disciplines that may apply to sunset reviews are to be found in Article 11.3 AD Agreement. The US submitted that this implies, for example, that a cumulative assessment of likely injury of imports from several countries ('injury cumulation'), which is not mentioned in Article 11.3, is not prohibited in sunset reviews. It is permitted as a practice without the need to comply with the specific disciplines of Article 3.3 AD Agreement, as such disciplines apply only to original investigations. Similarly, there is no textual basis for introducing a requirement to establish a causal link between likely future dumping and likely future injury.

With respect to the challenge by Mexico of US sunset provisions as such, the US considered that the SPB cannot be challenged as such before the WTO. In particular, the US emphasized that the SPB is not a binding legal instrument in US law and is meant simply as a transparency tool. It cannot require any particular action and is, therefore, incapable of breaching the US's obligations under the AD Agreement. In any case, it argued, the three factual scenarios set forth in the SPB are not determinative or conclusive and do not require the USDOC to rule affirmatively on the likelihood of continuation or recurrence of dumping in any case in which one of the three criteria of Section II.A.3 of SPB has been satisfied. The USDOC has discretionary authority to examine other evidence and base its determination on such other evidence. According to the US, the fact that this has not happened so far does not imply that the authorities lack the discretion to deviate from the scenarios of the SPB.

\section{The Report - Panel and Appellate Body}

\section{The challenge of the SPB}

\section{The Panel}

The Panel first examined whether the Sunset Policy Bulletin was indeed a 'measure' that could be challenged through WTO dispute settlement proceedings and, if so, whether its provisions were inconsistent with the US's obligations under the AD Agreement. ${ }^{6}$ The Panel was of the view that the first question had been answered affirmatively by the Appellate Body in previous cases such as US-Corrosion Resistant Steel and US-Oil Country Tubular Goods Sunset Reviews ${ }^{7}$ finding that 'any act or omission attributable to a WTO Member can be

\footnotetext{
6 In this section, we discuss the most important issues addressed by the Panel and the Appellate Body in respect of Mexico's claims. An important number of Mexico's claims were addressed and rejected by the Panel but were not the subject of an appeal. We therefore did not include them in our discussion. In any case, most of these claims concerned issues already dealt with in previous sunset review cases and did not present any novel or systemically important question.

7 Appellate Body Report, United States - Sunset Reviews of Anti-Dumping Measures on Oil Country Tubular Goods from Argentina ('US - Oil Country Tubular Goods Sunset Reviews'), WT/DS268/AB/R, para. 189, adopted 17 December 2004, affirming finding of the Panel that the SPB is a 'measure' subject to WTO dispute settlement, Panel Report, United States - Sunset Reviews of Anti-Dumping Measures on Oil Country Tubular Goods from Argentina (US-Oil Country Tubular Goods Sunset Reviews),
} 
a measure of that Member for purposes of dispute settlement proceedings' 8 The Panel further referred to the Appellate Body's conclusions that any legal instrument under a WTO Member's law could also be challenged as a measure before a WTO panel irrespective of the way in which it operates in individual cases. ${ }^{9}$ As the Appellate Body was dealing in both cases with the same SPB, the Panel, without any further ado, reached the conclusion that the SPB was a 'measure subject to WTO dispute settlement'. ${ }^{10}$

With respect to the question of what is required under the $\mathrm{AD}$ agreement, the Panel adopted the findings of earlier Appellate Body reports that Article 11.3 AD Agreement requires that a likelihood determination in a sunset review be made 'on a sufficient factual basis'. This implies that an investigating authority cannot base its determination on presumptions, to the exclusion of a full examination of the factual circumstances. ${ }^{11}$ The Panel thus concluded that the relevant question to address was whether the scenarios based on the two factors (i.e., import volumes and historical dumping margins) are treated as determinative or conclusive, or merely indicative or probative. ${ }^{12}$ If the latter was the case, no violation would exist.

The Panel examined the text of the SPB and came to the conclusion that it was not clear from the text whether the three scenarios based on import volumes and dumping margins were considered determinative or merely indicative. It thus decided to examine how the SPB had been applied in the past by the USDOC. In so doing, the Panel took to heart the warning given by the Appellate Body in US - Oil Country Tubular Goods Sunset Reviews case that such an analysis could not be based on 'mere statistical evidence'. The Panel decided that it would conduct a qualitative assessment of the evidence before it to see whether the affirmative determinations were made solely on the basis of one of the scenarios to the exclusion of other factors, in line with the guidance provided by the Appellate Body in US - Oil Country Tubular Goods Sunset Reviews. ${ }^{13}$

WT/DS268/R, at para. 7.136, adopted 17 December 2004 as modified by the Appellate Body Report, WT/DS268/AB/R.

8 Appellate Body Report, United States - Sunset Review of Anti-Dumping Duties on CorrosionResistant Carbon Steel Flat Products from Japan (US-Corrosion-Resistant Steel Sunset Review), WT/DS244/AB/R, adopted 9 January 2004, para. 81.

9 Ibid., para. 82.

10 Panel Report, 282/R, para. 7.24.

11 Appellate Body Report, US - Corrosion-Resistant Steel Sunset Review, paras. 178, 191.

12 Panel Report, 282/R, para. 7.30.

13 The Panel specifically recalled the following guidance by the $\mathrm{AB}$ in that case that:

in order to objectively assess, as required by Article 11 of the DSU, whether the three factual scenarios of Section II.A.3 of the SPB are regarded as determinative/conclusive, it is essential to examine concrete examples of cases where the likelihood determination of continuation or recurrence of dumping was based solely on one of the scenarios of Section II.A.3 of the SPB, even though the probative value of other factors might have outweighed that of the identified scenario. Such an examination requires a qualitative assessment of the likelihood determinations in individual cases.

AB Report, US - Oil Country Tubular Goods Sunset Reviews, para. 209, as referred to in Panel Report, 282/R, para. 7.49 . 
Based on its analysis of 232 determinations, it came to the conclusion that despite the apparent recognition that it may do otherwise, USDOC has consistently based its determinations in sunset reviews exclusively on the scenarios, to the disregard of other factors. We quote from para. 7.63 of the report:

In summary, our qualitative analysis of USDOC decisions reveals a clear picture. In almost all cases, USDOC begins with a recitation of the SPB scenarios. In the simplest cases, the determinations then recite facts fitting one of the scenarios, and USDOC concludes that there is a likelihood of continuation or recurrence of dumping. In other cases, USDOC seems clearly to have made its decision based exclusively on the SPB, without giving consideration to other potentially probative factors in evidence. We consider it telling that some of the determinations appear to indicate that the USDOC perceives the SPB scenarios as conclusive or determinative to the extent of obviating any necessity even to admit, let alone weigh, evidence as to other factors. In a few cases, USDOC appears at the outset willing to consider whether other factors may be relevant or probative, but does not ultimately rely on such factors, dismissing them summarily or not discussing them at all, and basing its final determination on evidence fitting the SPB scenarios. We emphasize that we are not focusing solely on the outcomes in these sunset reviews, but rather on our qualitative analysis of the determinations, and what we can discern about USDOC's decision-making process underlying those determinations. We therefore conclude that, despite the apparent recognition that it may do otherwise, USDOC has consistently based its determinations in sunset reviews exclusively on the scenarios, to the disregard of other factors. In our view, the actual determinations made, which in all cases ultimately conform to the results predicted by the SPB scenarios, belie the conclusion that USDOC does not consider them as conclusive or determinative in sunset reviews.

It thus concluded that the SPB established an irrefutable presumption of affirmative likely dumping in case one of the factual scenarios of the SPB was found to exist. The Panel found that, as Article 11.3 AD Agreement does not allow for such irrefutable presumption, Mexico had demonstrated that the SPB is, as such, inconsistent with Article 11.3 of the AD Agreement.

When it came to the specific determination of likelihood of dumping in case of OCTG imports from Mexico, the Panel was of the view that the USDOC, applying its policy of looking at the three specific scenarios, based its conclusions entirely on a decline in import volumes following the imposition of the order, and disregarded potentially relevant other evidence. Since the Panel was of the view that in a sunset review under Article 11.3 AD Agreement, an authority must act with an appropriate degree of diligence and arrive at a reasoned conclusion on the basis of information gathered as part of a process of reconsideration and examination, ${ }^{14}$

14 The Panel referred to the view expressed by the Appellate Body in US - Corrosion-Resistant Steel Sunset Review, paras. 111-115. 
the USDOC determination of likely dumping was considered inconsistent with the requirements of Article 11.3 AD Agreement. ${ }^{15}$

\section{The Appellate Body}

The United States appealed the Panel's finding that Section II.A.3 of the SPB is, as such, inconsistent with Article 11.3 of the Anti-Dumping Agreement, contending that the Panel failed to correctly apply the applicable legal standard in its assessment of the consistency of the SPB. It did not appeal the findings of the Panel in respect of the specific case of Mexican OCTG imports.

The Appellate Body upheld the US's challenge of the Panel's determination of inconsistency of the SPB, and overturned the Panel in this respect. The AB examined the Panel's analysis and came to the conclusion that it failed to live up to the standard of a 'qualitative assessment' it had set for itself. What the Panel should have examined, in the AB's view, was whether, and how relevant and probative, factors outside the scenarios were considered by the USDOC. As the nature and extent of the evidence to rebut the presumptions of the scenarios varies depending on the applicable scenario, a Panel cannot conduct a 'qualitative assessment' without examining how such counterevidence was dealt with. The AB thus came to the overall conclusion that:

the Panel's analysis does not reveal that the affirmative determinations, in the 21 specific cases reviewed by it, were based exclusively on the scenarios to the disregard of other factors. Nor does the Panel's review of these cases reveal that the USDOC's affirmative determinations were based solely on the SPB scenarios, when the probative value of other factors might have outweighed that of the identified scenarios. Accordingly, we conclude that the Panel did not conduct a 'qualitative assessment' of the USDOC's determination such that the Panel could properly conclude that the SPB requires the USDOC to treat the factual scenarios of Section II.A.3 of the SPB as determinative or conclusive. ${ }^{16}$

Having overturned the Panel's decision, the AB concluded that the Panel's statement of inconsistency of the SPB was 'moot and of no legal effect'. ${ }^{17}$

\section{Likelihood of injury}

\section{The Panel}

The Panel rejected all of Mexico's injury-related claims. The Panel considered that the Article 3 disciplines on 'injury' do not apply to determinations of 'likelihood of injury' in sunset reviews. It crucially relied on the reasoning of the $\mathrm{AB}$ in

15 The Panel noted for example that the USDOC did not rely on information concerning historical dumping margins, including the information on dumping margins calculated in administrative reviews during the period of time that the measure had been in place. Nor did USDOC otherwise consider any evidence relating to the amount of dumping originally found, the basis of that calculation, or whether changes in the underlying financial situation might affect the question of likelihood of continuation or recurrence of dumping. Panel Report, para. 7.78.

16 Appellate Body Report, para. 209.

17 Appellate Body Report, para. 211. 


\section{US-Corrosion Resistant Steel and US-Oil Country Tubular Goods Sunset} Reviews concerning the difference between original investigations and reviews. The Panel considered that a determination of injury is not the same as a determination of likelihood of continuation or recurrence of injury in a sunset review, and that, consequently, requirements relevant to a determination of injury are not necessarily relevant to a determination of continuation or recurrence of injury. It concluded that an investigating authority is not required to make an injury determination in a sunset review, and that, therefore, the obligations set out in Article 3 AD Agreement are not directly applicable in sunset reviews. ${ }^{18}$ Still, the Panel added, the provisions of Article 3 governing the determination of injury may provide useful guidance in the context of the analysis in sunset reviews. ${ }^{19}$

\section{The Appellate Body}

Mexico's limited appeal of the Panel's findings in respect of the applicability of Article 3 AD Agreement to sunset reviews concerned the Panel's interpretation of Article 11.3 of the Anti-Dumping Agreement and its failure to address the 'inherent' causation requirements under that Article. Referring to the underlying principles in the Anti-Dumping Agreement ${ }^{20}$ and Article VI of the GATT 1994, Mexico argued that, even assuming that Article 3.5 of the Anti-Dumping Agreement (dealing with causation) does not apply directly to sunset reviews, the Panel failed to recognize the 'inherent' obligation to establish a causal link between likely dumping and likely injury in a sunset review determination under Article 11.3 of the Anti-Dumping Agreement.

The $\mathrm{AB}$ rejected Mexico's argument of an inherent requirement to conduct a causation analysis under Article 11.3 AD Agreement. On the one hand, the AB agreed with Mexico that the existence of a causal link between dumping and injury to the domestic industry is fundamental to the imposition and maintenance of an anti-dumping duty under the Anti-Dumping Agreement. In the words of the AB:

an anti-dumping duty can be imposed and maintained only if the dumping (as properly established) causes injury to the domestic industry. Absent injury to the domestic industry, the rationale for either imposing the duty in the first place, or maintaining it at any time after its imposition, does not exist. ${ }^{21}$

On the other hand, the AB held the view that because the 'review' contemplated in Article 11.3 AD Agreement is a 'distinct' process with a 'different' purpose from the original investigation, a causal link between dumping and injury is not required to be established anew in a sunset review. The $\mathrm{AB}$ considered that in a sunset review, the nexus to be demonstrated is between 'the expiry of the duty' on

18 Panel Report, para. 7.117.

19 The Panel further rejected all of Mexico's arguments that the USITC did not base its 'likelihood of injury' determination on a sufficient factual basis. It considered that the USITC determination was based on positive evidence and supported by adequate reasoning.

20 Mexico referred to Articles 1, 3, 11.1, and 18.1 of the AD Agreement in particular.

21 Appellate Body Report, para. 117. 
the one hand, and the likelihood of 'continuation or recurrence of dumping and injury' on the other hand. What is required under Article 11.3 is the effect of the expiry of the duty on the likelihood of continuation or recurrence of dumping and injury. ${ }^{22}$ The $\mathrm{AB}$ did not consider that the requirement of establishing a causal link between likely dumping and likely injury necessarily flows into that Article from other provisions of the GATT 1994 and the Anti-Dumping Agreement. According to the $\mathrm{AB}$, 'adding such a requirement would have the effect of converting the sunset review into an original investigation, which cannot be justified'. ${ }^{23}$ The AB hastened to add that this did not imply that the causal link between dumping and injury envisaged by Article VI of the GATT 1994 and the Anti-Dumping Agreement was severed in a sunset review. It would only mean that reestablishing such a link is not required, as a matter of legal obligation, in a sunset review. ${ }^{24}$

\section{Cumulation}

\section{The Panel}

The Panel did not accept Mexico's arguments that, in sunset reviews, it is not permissible to cumulatively assess the effects of imports from various countries subject to the order. Neither did it consider convincing Mexico's alternative argument that in case such cumulation were permitted, the same disciplines as are imposed by Article 3.3 AD Agreement in respect of cumulation in original investigations would necessarily also apply in a sunset review context.

The Panel was of the view that the silence of the AD Agreement on the question of cumulation in sunset reviews is properly understood to mean that cumulation is permitted in sunset reviews. It referred to the finding of the Appellate Body in US - Oil Country Tubular Goods Sunset Reviews, which dealt with the exact same question. In that case, the $\mathrm{AB}$ concluded that cumulation is permitted in sunset reviews and that, since the disciplines of Article 3.3 AD Agreement are limited to original investigations, such disciplines do not apply in sunset reviews.

\section{The Appellate Body}

On appeal, Mexico argued that, irrespective of whether the specific obligations of Article 3.3 AD Agreement applied to sunset reviews, the USITC was under an obligation to ensure that cumulation was appropriate in light of the conditions of competition. It argued that, to do that, the USITC was required to make a threshold finding that the subject imports would be simultaneously present in the US market. According to Mexico, the Panel erred in declining to examine and make findings on this issue. In this respect, Mexico argued that nowhere in the USITC's analysis was there positive evidence demonstrating that imports from

22 Any such determinations under Article 11.3 must rest on a 'sufficient factual basis' that allows the investigating authority to draw 'reasoned and adequate conclusions'. See, for example, Appellate Body Report, US - Oil Country Tubular Goods Sunset Reviews, para. 311.

23 Appellate Body Report, para. 123.

24 Appellate Body Report, para. 124. 
Mexico, and imports from Argentina, Italy, Korea, and Japan would be present in the United States market at the same time if the order were revoked. In any case, Mexico was of the view that having decided to cumulate Mexican imports with imports from four other countries, the USITC was required to do so consistently with the requirements of Article 3.3, regardless of whether that provision applies directly to sunset reviews.

The $\mathrm{AB}$ disagreed both with respect to the inherent 'simultaneous presence' argument and with respect to the general applicability of the disciplines of Article 3.3.

The AB failed to see why the USITC was required, under Article 11.3 AD Agreement, to follow the specific step of making a 'threshold finding' on the simultaneous presence of subject imports before resorting to cumulation, ${ }^{25}$ given the fact that Article 11.3 does not prescribe any particular methodology with respect to cumulation in sunset reviews. ${ }^{26}$

In addition, the $\mathrm{AB}$ clearly established the fact that the disciplines of Article 3.3 relating to cumulation in original investigations do not apply per se in sunset reviews under Article 11.3. In its typical fashion, the $A B$ added the following caveat:

We do not, however, suggest that, when an authority chooses to cumulate imports in a likelihood-of-injury determination under Article 11.3, it is never necessary for it to determine whether such a cumulative assessment is appropriate in the light of the conditions of competition in the market place. In particular cases, a cumulative assessment of the effects of the imports may be found to be inappropriate and, therefore, inconsistent with the fundamental requirement that a determination rest on a sufficient factual basis and reasoned and adequate conclusions. ${ }^{27}$ However, this fundamental requirement derives from the obligations under Article 11.3 itself, and not from the conditions specified in Article $3.3 .^{28}$

25 Appellate Body Report, para. 152.

26 Typically, the $\mathrm{AB}$ offered the following attenuation of its statement that no such determination of simultaneous presence is required:

This is not to say that it is never necessary for an investigating authority, performing a cumulative analysis of injury caused by imports from all sources, to examine whether imports are 'in the market together and competing against each other.' In order to arrive at a reasoned and adequate conclusion, an examination of whether imports are in the market together and competing against each other may, in certain cases, be needed in a likelihood-of-injury determination where an investigating authority chooses to cumulate the imports from several countries. But the need for such an examination flows from the particular facts and circumstances of a given case and not from a legal requirement under Article 11.3.

Appellate Body Report, para. 153.

27 See Appellate Body Report, US - Oil Country Tubular Goods Sunset Reviews, para. 284.

28 Appellate Body Report, para. 171. 


\section{Analysis}

\section{Legal analysis}

The case discussed in this report was the fourth and so far final one dealing with sunset reviews, and, not surprisingly, built on a number of such previous Panel and Appellate Body reports. We will, therefore, first provide a quick overview of the basic conclusions to draw from the sunset case law to date. Thereafter, we will briefly comment on the Appellate Body's finding in this case that no causation analysis is required in sunset reviews. Third, we address the AB's analysis of the Panel's decision in respect of the Sunset Policy Bulletin.

\section{Sunset reviews - an empty box?}

Only one provision of the AD Agreement explicitly deals with sunset reviews, Article 11.3 AD Agreement. It does not say much but simply sets forth two key principles: (1) that anti-dumping duties are to be terminated after five years; and (2) that by way of exception, duties may remain in place for a longer period of time if it is determined in a review that the expiry of the duty would be likely to lead to continuation or recurrence of dumping and injury. That is all that the text of the $\mathrm{AD}$ Agreement provides for in respect of sunset reviews. ${ }^{29}$ All the sunset disputes dealt with by WTO panels and the $\mathrm{AB}$ revolved around the question whether some of the more detailed requirements about dumping and injury, as reflected in various provisions of the AD Agreement, as well as many of the procedural rules developed with respect to original investigations also apply to sunset reviews.

The commonsense argument is clear. A sunset review is more or less like a new investigation, and may take up to one year to conclude; it is about dumping and injury, terms defined in Articles 2 and 3 of the Agreement; an investigation is required, and the Agreement explicitly imposes respect for the procedural and evidentiary safeguards of original investigations also in the conduct of such review investigations. While the outcome of a review is different from the outcome of an original investigation, i.e. whether dumping and injury would be likely to recur rather than whether dumping and injury exist, the concepts used and the process followed are very similar. Nevertheless, the text of Article 11.3 does not crossreference to these provisions of the AD Agreement in which dumping and injury are detailed. It does not contain any disciplines in terms of methodology to follow in sunset reviews. So the choice before the WTO panels and the AB was fundamentally the following: do we follow a strict textual approach or do we prefer a contextual approach based on common sense. The latter approach would inevitably lead to the introduction of a number of disciplines in sunset reviews, and thus limit the discretion of the investigating authority. Confronted with that choice on a number of occasions, the $\mathrm{AB}$ consistently opted for the strict textual approach and preserved to the maximum extent possible the investigating authority's

29 Article 11.4 adds that insofar as procedure and evidence are concerned, everything that was provided for with respect to original investigations also applies to reviews such as a sunset review. 
discretionary authority in extending anti-dumping measures beyond the envisaged maximum period of five years.

The argument offered by the $\mathrm{AB}$ was basically that sunset reviews and original investigations are different processes with a different purpose,${ }^{30}$ to which different rules apply. The rules and disciplines for making a determination of dumping and injury that apply in original investigations, are not applicable as such in sunset reviews. ${ }^{31}$ In respect of the likelihood-of-injury determination, the $\mathrm{AB}$, in its report on US-Oil Country Tubular Goods Sunset Reviews, was of the view that no injury examination in the sense of Article $3 \mathrm{AD}$ Agreement is required and that, therefore, the obligations set out in Article 3 do not apply in sunset reviews. ${ }^{32}$ The same approach governed the likelihood of dumping determination. The AB was of the view that the silence on the methodology for determining likelihood of dumping in Article 11.3 suggests that no obligation is imposed on investigating authorities to calculate or rely on dumping margins in a sunset review. This is so because, in a sunset review, dumping margins may well be relevant, but will not necessarily be conclusive of whether the expiry of the duty would be likely to lead to continuation or recurrence of dumping. In an original investigation, however, a positive margin determination is a necessary condition for the imposition of a measure. $^{33}$

It appeared that by taking this approach the Appellate Body was voiding of all meaning the need to conduct a sunset review. The hard-fought rule that duties could not stay in place forever, but were to be terminated after five years, becomes meaningless. If no disciplines apply to sunset reviews, such reviews become a formality; as has happened in practice in certain countries, an anti-dumping duty will in effect be extended quasi-automatically every five years.

Obviously concerned about this outcome, the AB decided to attenuate its hard line: it started to read things into a couple of the terms that appear in Article 11.3 and on that basis imposed some basic general limitations on an authority's freedom. While it refused to read the terms 'dumping' and 'injury' in context, the terms 'review' and 'determination' were interpreted as if they operated like Russian dolls containing a number of different obligations.

Based on the fact that a sunset 'review' requires a 'determination' of likely dumping and injury, the primary obligation the $\mathrm{AB}$ imposed on investigating authorities became to ensure that their determination of likelihood of recurrence or continuation of dumping and injury rests on a sufficient factual basis that allows the investigating authority to draw reasoned and adequate conclusions. The $\mathrm{AB}$, in

30 Appellate Body Report, US - Corrosion-Resistant Steel Sunset Review, paras. 106-107; Appellate Body Report, US - Carbon Steel, para. 87.

31 Appellate Body Report, on US - Oil Country Tubular Goods Sunset Reviews, para. 359.

32 Appellate Body Report, US - Oil Country Tubular Goods Sunset Reviews, para. 280. Also see Panel Report, US - Anti-Dumping Measures on Oil Country Tubular Goods, para. 7.117.

33 Appellate Body Report, US - Corrosion-Resistant Steel Sunset Review, paras. 123-124. 
its report on US-Oil Country Tubular Goods Sunset Reviews explained its reasoning as follows:

In US - Corrosion-Resistant Steel Sunset Review, the Appellate Body emphasized the importance of the terms 'determine' and 'review' in Article 11.3, stating:

The words 'review' and 'determine' in Article 11.3 suggest that authorities conducting a sunset review must act with an appropriate degree of diligence and arrive at a reasoned conclusion on the basis of information gathered as part of a process of reconsideration and examination. (emphasis added)

The Appellate Body also endorsed that Panel's description of the obligation contained in Article 11.3, which description the Appellate Body found 'closely resemble[d]' its own understanding:

The requirement to make a 'determination' concerning likelihood therefore precludes an investigating authority from simply assuming that likelihood exists. In order to continue the imposition of the measure after the expiry of the five-year application period, it is clear that the investigating authority has to determine, on the basis of positive evidence, that termination of the duty is likely to lead to continuation or recurrence of dumping and injury. An investigating authority must have a sufficient factual basis to allow it to draw reasoned and adequate conclusions concerning the likelihood of such continuation or recurrence. (emphasis added; original footnotes omitted)

The plain meaning of the terms 'review' and 'determine' in Article 11.3, therefore, compel an investigating authority in a sunset review to undertake an examination, on the basis of positive evidence, of the likelihood of continuation or recurrence of dumping and injury. In drawing conclusions from that examination, the investigating authority must arrive at a reasoned determination resting on a sufficient factual basis; it may not rely on assumptions or conjecture. ${ }^{34}$

It is clear that suddenly the $\mathrm{AB}$ showed a great willingness to read a lot into two words. It imposed some important basic disciplines on sunset reviews. While we welcome in general such a development, we cannot help wondering why a similar approach in favor of importing some of the disciplines in terms of dumping and injury was rejected. To read such obligations into words as 'determination' and 'review' is not more textual than it would have been to do the same for dumping and injury. In other words, if one wanted to be consistent, the only solution would be to say that there simply are no disciplines imposed by the text of Article 11.3 and that the drafters had been sloppy by not cross-referencing the obligations that apply in original investigations.

At the same time, and in light of the lack of any serious economic justification for the use of anti-dumping, we do not want to be seen as suggesting that we disagree with the introduction of such disciplines by the AB. While consistency is certainly a virtue, one can also be consistently wrong. We should thus be happy with this lack of consistency by the $\mathrm{AB}$ in its approach to sunset reviews, which

34 Appellate Body Report, US - Oil Country Tubular Goods Sunset Reviews, paras. 179-180. 
were starting to look very much like an empty box. At least the box is not completely empty now.

How full it is remains to be seen. While a requirement is introduced to base the determination on facts and positive evidence, a sunset review is by definition a forward-looking exercise. Even the AB thus admitted that some speculation about future events cannot be avoided. ${ }^{35}$ Moreover, the demands on the type of evidence on which the determination is to be based are minimal. Limited observations, in the sense of small volume of export sales, might suffice for the purposes of conducting a lawful review. ${ }^{36}$ More importantly, data that were evaluated in the original investigation may be used again and reevaluated at the review stage as 'a fresh determination, based on credible evidence'. ${ }^{37}$ This implies that it may be justified to base a sunset determination of likely dumping on data from more than five years ago. At first glance, this seems troublesome. A prospective analysis as the one allegedly undertaken in a sunset review (i.e., will there be likely dumping and injury in case the duty is removed?) should be based on the most recent data, it would seem. One could argue that a prospective analysis based on data from more than five years ago can hardly be called meaningful. However, as we discuss in more detail below in the economics section, more recent data are not necessarily more relevant for the likelihood determination given that the data being used for comparison would be derived from a set of historical market conditions (under the order) that we anticipate would be quite different from the future market conditions (were the order to be removed).

Moreover, while the basic due-process rights applicable in original investigations have been applied to sunset reviews, the $\mathrm{AB}$ accepted one important exception: in sunset reviews, no individual determination of the need to maintain the duty with respect to the individual exporter is required. ${ }^{38}$ This of course has the important consequence that a company can remain subject to an anti-dumping order even though it is no longer dumping. Its sales will continue to be monitored and remain under threat of anti-dumping action for another five years. But how can this be squared with the insistence on the need to have a sufficient factual basis for maintaining the duties; dumping is a practice of individual companies, it is not

35 Appellate Body Report, US - Oil Country Tubular Goods Sunset Reviews, para. 341.

36 Appellate Body Report, US - Oil Country Tubular Goods Sunset Reviews, para. 346:

We endorse the Panel's view that ' $[\mathrm{t}]$ he simple fact that the number of price comparisons was limited does not make this aspect of the USITC's determination inconsistent with Article 11.3 of the [Anti-Dumping Agreement]',

Also see Panel Report, US - Oil Country Tubular Goods Sunset Reviews, para. 7.303.

37 Appellate Body Report, US - Carbon Steel, para. 88.

38 In its report on US - Corrosion-Resistant Carbon Steel Sunset Review, the AB considered that paragraph 10 of Article 6, requiring the authority to calculate individual margins of dumping cannot apply in a review because, according to the Appellate Body, in a review, an authority is not required under Article 11.3 to calculate dumping margins in the first place. Appellate Body Report, US-Corrosion Resistant Steel Sunset Reviews, para. 155. 
something countries engage in. Yet, if the facts support a determination that one or more exporters are likely to continue or restart dumping, all exporters remain subject to anti-dumping duties. The sunset review may well be based on facts in such circumstances, simply not necessarily on facts relevant to the exporter allegedly engaged in dumping. How does all this fit together? Only the AB knows.

Causation - required to keep the duty in place?

Dumping, injury, and the existence of causal link between the two are the basic conditions for any anti-dumping action. If there is no dumping, no duty may be imposed to offer protection to a domestic industry, even though it may be faring badly and could be said to be suffering 'injury'. Similarly, if imports are being dumped on the market, but the domestic industry in the importing country is healthy and profitable, no duties may be imposed, since the industry is not in a state of 'injury'. Likewise, imports may be dumped into a country, and during that same period of time the domestic industry may be going through a difficult period of loss of profitability and lay-offs, but still no protection can be offered through the imposition of anti-dumping duties unless it can be demonstrated that the dumped imports are the cause of this negative situation. The causation requirement thus plays an important role in preventing countries from passing on to exporting countries the costs of bad industrial management, lack of adequate investment in new technology, and a failed industrial policy in general.

In the case discussed in more detail in this report, US - Anti-Dumping Measures on Oil Country Tubular Goods, the Appellate Body confirmed, on the one hand, that a causal link between dumping and injury to the domestic industry is fundamental to the imposition and maintenance of an anti-dumping duty under the AD Agreement. However, on the other hand, and in line with the alleged textual approach outlined above, it also stressed the fact that the text of Article 11.3 does not require the establishment of a causal link between the likely injury and the likely dumping. It held the view that a sunset review is a distinct process with a 'different' purpose from the original investigation, and that therefore a causal link between dumping and injury is not 'required to be established anew in a review conducted under Article 11.3' '. ${ }^{39}$ According to the Appellate Body, 'adding such a requirement [of establishing a causal link between the likely dumping and likely injury] would have the effect of converting the sunset review into an original investigation, which cannot be justified ' ${ }^{40}$

The Appellate Body considered that the nexus to be demonstrated under Article 11.3 is not between dumping and injury, but between 'the expiry of the duty' on the one hand, and the likelihood of 'continuation or recurrence of dumping and injury' on the other hand.

39 Appellate Body Report, US - Anti-Dumping Measures on Oil Country Tubular Goods, para. 118. 40 Appellate Body Report, US - Anti-Dumping Measures on Oil Country Tubular Goods, para. 123. 
However, to conclude on this basis that there is no need to establish a causal link between the likely future dumping and injury seems problematic to say the least. In our view, an examination of likelihood of recurrence or continuation of injury must refer to likelihood of injury insofar as it is caused by dumping, and not just any injury. Even under a strict textual approach, the Appellate Body erred by introducing such an artificial separation between injury and causation, since the only relevant injury under the AD Agreement is the injury caused by the dumped imports. Look at the text of the AD Agreement: injury and causation are both discussed in the same provision, Article 3 of the AD Agreement, entitled, Determination of Injury. So, there is no separate provision dealing with causation. While the requirement to establish a causal relationship between dumping and injury is expressed in one paragraph of Article 3, Article 3.5 AD Agreement, this is not the only paragraph of Article 3 linking injury to the dumped imports. Various other paragraphs of Article 3 such as for example Articles 3.1, 3.2, and 3.4, refer to the volume of dumped imports and the effects of such imports on domestic prices as well as the impact of these imports on domestic producers. In other words, such provisions do not simply set forth an analysis of the state of the domestic industry as such, quite to the contrary. They are all geared at establishing the existence of injury caused by dumped imports. ${ }^{41}$ In our view, the Appellate Body's textual arguments separating injury from causation are misplaced, and its interpretation is not faithful to the text of the AD Agreement.

This being said, two additional comments are in place to put this error in the right perspective.

First, in practice, we wonder whether the Appellate Body's error will have much impact, as it seems that the $\mathrm{AB}$ was not willing to accept the consequences of its own ruling. It appears that a causation requirement was brought in through the back door: the need to establish a nexus between the termination of the duty and the likely dumping and injury that would follow.

Since it must be demonstrated on the basis of positive evidence that there exists a nexus between the expiry of the duty and the recurrence or continuation of dumping and injury, an investigating authority cannot simply ignore the intervening effect of an influx of imports from other sources, or an event such as a storm destroying a factory for example. The injury may continue, but it has nothing to do with the expiry of the duty, rather it is caused by an intervening factor, the nonsubject imports, or the storm. In other words, it needs to be established that the expiry of the duty, which assumingly was protecting the industry from injury by

41 For example, Article 3.2 requires that it be examined whether there has been an increase in the volume of dumped imports. This is part of the 'injury' analysis, even though the volume of dumped imports is not informative of the state of the domestic industry as such. It is important in establishing the link between dumped imports and the injurious state of the domestic industry. In other words, an examination of the volume of dumped imports and their price effects are elements of a causation analysis, rather than an injury analysis pur sang. So, the relevant injury of the AD Agreement is a qualified 'injury caused by' dumped imports. 
offsetting the dumping, is the cause of the recurring dumping and injury. If a storm or nondumped imports are the cause of the industry's problems, then the expiry of the duty cannot be blamed for such recurrent injury. Indirectly, therefore, the requirement of a nexus between the expiry of the duty and the likely dumping and injury imposes the establishment of a nexus between the dumped imports and the injury. So maybe the Appellate Body's sweeping statements about the absence of the need to establish a causal link between dumping and injury in sunset reviews is much ado about nothing ('Mucho ruido, pocas nueces', as the Mexicans would say).

This, of course, begs the question why the AB felt it was necessary to adopt such an overly restrictive and incorrect textual interpretation of the requirements of Article 11.3 and the term 'injury' in particular. The only explanation we can come up with is a fear of imposing disciplines and obligations on investigating authorities beyond what a strict, minimalist, and therefore incorrect reading of the text allows for.

A second comment is that, as we discuss in more detail below in the economic analysis section, it is not straightforward to establish an empirically and economically satisfactory causal relationship between future dumping and future injury. While that may be so, we note that it was not for such sound economic reasons that the $\mathrm{AB}$ concluded that causation was not an element to be established in a sunset review determination. Neither do we wish to suggest by this economic comment that the difficulty of establishing such a causal link would be a good reason for allowing the continuation of duties without further ado, quite to the contrary. The fact that it is difficult to come to any meaningful conclusion about such future events should be a reason for requiring termination of such measures. Any extension can only be based on speculation.

\section{The SPB - the impossible task of demonstrating a violation}

The Sunset Policy Bulletin (SPB) saga continued in this case. We recall that this was the third case to deal with the US Sunset Policy Bulletin, the ins and outs of which have been explained in the ALI report dealing with the dispute on US - Oil Country Tubular Goods Sunset Reviews. In essence, the SPB sets forth the USDOC's policy for determining whether dumping is likely to continue or recur when the anti-dumping duty expires. It provides for three factual scenarios centered around two criteria: import volumes and dumping margins. In case the facts are consistent with any of these scenarios, the SPB provides that the USDOC 'will normally' conclude that there is a likelihood that the exporters will continue or resume dumping their products into the importing country. A number of WTO Members have taken issue with the SPB as it sets forth certain basic assumptions on the basis of which the USDOC will reach its conclusions without regard to other evidence rebutting the validity of such assumptions. It was therefore argued to be inconsistent with the basic principle that a determination and review be based on facts and positive evidence, not assumptions. 
The first Panel to deal with the consistency of the SPB in US-Corrosion Resistant Steel Sunset Review (DS 244) considered that the SPB was not a mandatory piece of legislation and concluded that, for that reason, it did not constitute a 'measure' that could be challenged through WTO dispute settlement proceedings. The $\mathrm{AB}$ overturned this decision stating that any act attributable to the State can be challenged as such before the WTO. It did not pronounce itself on the consistency of the SPB. A second Panel dealing with the SPB in US - Oil Country Tubular Goods Sunset Reviews followed the AB's jurisprudence and examined the SPB to find that it was inconsistent with the AD Agreement. But, this Panel, too, was overturned by the AB. The Panel's straightforward conclusion of inconsistency was based on consistent results of 232 affirmative sunset determinations all applying the three scenarios. The Panel was overturned by the AB because it failed to conduct a 'qualitative assessment' of the evidence and relied on 'mere statistical' evidence. The US - Anti-Dumping Measures on Oil Country Tubular Goods from Mexico case discussed in our report was thus the third case to deal with the SPB. The Panel was clearly aware of the errors committed by previous Panels, as it recalled the 'guidance' of the Appellate Body in terms of the legal standard for determining whether the SPB was inconsistent with the Agreement and the type of qualitative assessment a Panel is to undertake in order to establish any inconsistency based on the evidence before it. And yet, once again, the Panel got it wrong. At least, according to the AB.

We do not want to dwell on the comments of the $\mathrm{AB}$ with respect to the specific analysis of the Panel in this case. But we cannot but wonder why the Appellate Body wants to fault the Panel for not having examined in detail 206 of the 232 cases that were decided in an 'expedited' manner. After all, these were all cases decided on the basis of the US waiver provisions that the same AB in US-Oil Country Tubular Goods Sunset Reviews found to be inconsistent with the AD Agreement's requirement that a determination of likelihood of dumping and injury be based on positive evidence and not just on assumptions. If these determinations were all inconsistent with the AD Agreement and not based on evidence or arguments provided by the investigated exporters, why would the Panel have needed to examine these cases in more detail?

In any case, what we want to highlight is how difficult it is to demonstrate a violation in case the text of the legal instrument is prima facie discretionary, such as is the case of the SPB. The SPB provides that the USDOC 'will normally' reach its conclusion on the basis of the three scenarios, but allows parties to present, if good cause is shown, other evidence rebutting the presumptive conclusions reached on the basis of the scenarios. What the 232 affirmative determinations of the USDOC revealed, however, was how illusory such a possibility proved to be, as every determination had been based on one of the scenarios. But what the AB wanted was proof that evidence undermining the assumptions established under any of the three scenarios was offered by an interested party, that such evidence was rejected, and that it was rejected because the USDOC felt obliged by the SPB 
to reach its conclusion on the basis of one of the three scenarios. Only then would it be possible to conclude that the SPB mandated WTO inconsistent action, only then would the SPB be inconsistent 'as such' with the AD Agreement. This is of course a Herculean task.

It is doubtful whether the $\mathrm{AB}$ would have reached the same conclusions with respect to the evidence of a consistent application of the three scenarios establishing a presumption of likelihood of dumping had there not been an SPB. In other words, had the USDOC practice been examined as such, i.e. as a 'practice', the outcome would most probably have been different. It is clear that the fact that the USDOC always applies the three scenarios and has never to date been willing to accept data and arguments that did not fall inside the scope of these three factual scenarios should be sufficient to establish a violation. The zeroing case law and the way the zeroing 'methodology' was considered to be an 'as such' violation of the requirements of the AD Agreement stands in stark contrast with the overly rigorous mandatory/discretionary approach advocated in this case. Given the importance of sunset reviews as the door to an extension of the duty for another five years, and given the acknowledgment by the $\mathrm{AB}$ itself that termination of a duty after five years is the rule, and extension the exception, this deferential approach is all the more surprising and disappointing. ${ }^{42}$

It is for reasons of predictability and a stable trading regime that GATT/WTO jurisprudence allows challenges of laws on an 'as such' basis, thus even without the application of such laws, and without a need to wait for the damage caused by such legislative violations to occur. The direct impact of trade laws was an important consideration in allowing such 'as such' challenges. By denying Members a realistic possibility to challenge such quasi-discretionary measures as the SPB, the $\mathrm{AB}$ is undermining the objective pursued by such 'as such' challenges. Each Member will be forced to challenge the actual application of the SPB, although it is clear that USDOC will always base itself on these doubtful and overly simplistic assumptions, discarding alternative evidence.

This hard line is even more surprising in this particular case in light of the clear criticism expressed by the $\mathrm{AB}$ with respect to the assumptions underlying the three scenarios. The $\mathrm{AB}$ objected to the presumptions established under these three scenarios as being a sufficient basis for making affirmative determinations. It considered that there were certain cases where the presumption was quite forceful, but that for other scenarios the presumption was more doubtful. According to the $\mathrm{AB}$, for example, a company's strategy and ability to increase or decrease its

42 So, after first having overturned the first Panel for not wanting to consider the possible violation contained in the SPB because it did not mandate any action, the AB has now de facto closed the circle making it clear that you may well be allowed to challenge such discretionary legislation 'as such', but you will never win the case. The evidentiary burden on a complainant is such that legislation that does not expressis verbis require WTO inconsistent action will never be found to be inconsistent as such with the WTO Agreement. The first Panel was right after all: let's not waste each other's time, this is a no-go from the beginning. 
exports to particular markets would need to be examined to be able to say anything about the future likelihood of dumping to stimulate an increase in imports. It would require an examination of a variety of market conditions, such as, in particular, the opportunities available in different markets and the competitive conditions in the marketplace. ${ }^{43}$ The USDOC never does such a thing but simply examines whether the facts of the case are covered by one of the three scenarios. If that is the case, it concludes that there is a likelihood of dumping. USDOC does not question the underlying assumptions.

In sum, it appears that many US sunset review determinations could be challenged before the WTO since all are based on the presumptions established by the SPB, yet the SPB itself remains untouchable. This is obviously not a desirable outcome.

We want to add one final systemic comment. The SPB saga demonstrates once again that the $\mathrm{AB}$ fails to introduce the expected predictability and uniformity in the dispute settlement process and does not clarify the legal obligations of the Agreement. Two Panels, both very much aware of what the Appellate Body had said in respect of the SPB and both expressly relying on the AB's statements in this respect, were overturned for having failed to correctly apply the Appellate Body's guidelines. Were both Panels too ignorant to understand what the $\mathrm{AB}$ was saying, or was the $\mathrm{AB}$ too vague in explaining what it considered to be required, and overly zealous in imposing respect for its own statements? We leave this to the reader to decide.

\section{Economic analysis}

This section provides an economic analysis of two key aspects of the Appellate Body's decision. First, we examine a role for causality between expected dumping and expected injury in the sunset review investigative process. Second, we provide an economic assessment of the use of cumulation in the likelihood-of-injury determination in the sunset review process. After addressing these issues in each of the next two sections, in the final section we return to the question of the economic importance of sunset reviews more broadly. ${ }^{44}$

\section{Causation in sunset reviews}

A key question at issue in the appeal is whether investigative authorities in the sunset review process are required to establish the existence of a causal link between likely dumping and likely injury. Before commencing our economic analysis of this question, we first review two foundational issues - what an economic

43 AB Report, US - OCTG Mexico, paras. 198-200. In fact, the scenarios are such that it will not be too difficult to reach affirmative determinations, which explains perhaps the fact that, unless the domestic industry was no longer interested in maintaining the order, every sunset review conducted by the USDOC has led to an affirmative finding.

44 There are a number of other economic issues associated with dumping involved in this dispute and decision that we choose not to address, given their substantial treatment in other contributions to this series. 
analysis contributes vis-à-vis the question of how investigative authorities first make the likelihood-of-dumping determination during a sunset review; and how economics assesses the importance of causality in anti-dumping investigations more generally. After reviewing these issues separately, we then tie together our analysis below.

Likelihood of continued or renewed dumping. When examining the question of whether it is likely that a foreign firm will continue or renew its dumping if an anti-dumping order were removed, we first review the insightful analysis of Howse and Staiger (2006). A concise summary of their fundamental reasoning is simply that 'a meaningful assessment of the likelihood of continued or renewed dumping requires an understanding of two things: (i) what conditions led to dumping in the first place; and (ii) whether those conditions have changed in a way that removes the original reason for dumping' (Howse and Staiger, 53).

With this statement, we highlight the fact that Howse and Staiger rule out an alternative methodology - which is that the likelihood of dumping determination be based on evidence from pricing data and dumping calculations collected while the anti-dumping order was imposed.

Howse and Staiger rule out this (prima facie) attractive alternative by pointing out that evidence that a firm dumped while under an anti-dumping order is not necessarily a useful predictor of whether the firm would also dump in the absence of a such an order - i.e., in the sunset review scenario that the anti-dumping order would be removed. Blonigen and Park (2004) provide a theoretical framework and supportive economic evidence based on the behavior of firms under US antidumping orders that serves as a compelling explanation for the Howse and Staiger argument. Because the USDOC carries out its dumping determination retrospectively, i.e., by examining past dumping behavior, Blonigen and Park show how this can create a (counterintuitive) incentive for profit-maximizing firms to increase their dumping margins because of the presence of an anti-dumping order. Blonigen and Park not only illustrate this incentive within a theoretical economic model, but they also provide empirical evidence from a sample of pricing decisions made by firms under US anti-dumping orders that is consistent with the theoretical model's predictions.

The economics of causality in anti-dumping investigations. Before examining the question of causality in the specific setting of sunset reviews, we provide a brief discussion of the importance of the causality issue within the more general context of the link between dumping and injury.

While there may be evidence of dumping and evidence of injury to the domestic industry in an anti-dumping investigation, economists argue for the need for a causal link because of concern that other more compelling factors may have contributed to 'causing' the injury. For example, at the same time that dumping takes place, the domestic industry may face other economic shocks unrelated to dumped subject imports. Examples of such other factors include 'supply-side' shocks such 
as cost shocks due to unexpected changes in energy prices or other key inputs, labor shortages (strikes), poor managerial decisions, or natural disasters; 'demand-side' shocks such as fluctuations in income or tastes and preferences; or even shocks to the level of nonsubject imports.

Because of the presence of many theoretically compelling, and yet potentially competing explanations of the cause of injury to a domestic industry, economists have developed formal, empirically based methodological frameworks that investigative authorities can use to help sort between explanations. Two such examples are an econometric approach and a simulation approach.

A typical econometric approach to examine the causality question would have investigators use a multivariate regression analysis to examine the statistical relationship between movements in recent values of possible competing explanatory variables (e.g. subject imports, energy or other input prices, nonsubject imports, etc.) and movements in recent values of measures of industry injury (e.g. profits, revenues, employment, capacity utilization, etc.). ${ }^{45}$ There are a number of reasons why, if there are no other constraints, the econometric approach can be the most compelling. For example, it is the most rigorous approach, as a properly specified regression framework allows the investigator to use data stemming from actual events to estimate how much of the injury is due to dumped imports, controlling for a number of other potential explanations for the injury. The drawback of this approach is that frequently there are realistic constraints to implementation, such as the fact that it may difficult or costly because it is very data intensive.

An alternative methodological framework that economists have developed to provide insight into the causation question is called a 'simulation' approach. The basic methodology is to use estimates of key economic parameters (e.g. demand, supply, and substitution elasticities) of the product market under investigation in combination with minimal data on changes in a few key market indicators (e.g. prices, domestic production, volume of subject and nonsubject imports, etc.) in order to come up with a rough, but economic-based assessment as to whether dumped imports are at least statistically a cause of injury. ${ }^{46}$ While such simulation exercises rely heavily on assumptions of the model's market structure and the reliability of elasticity assumptions obtained from other sources, and they do not provide as much information as a multivariate regression analysis, such an approach can be an attractive and low-cost alternative useful for examining whether the basic economic facts are consistent with a scenario in which dumped imports contributed to injury. Indeed, such an alternative may be particularly appealing

45 See, for example, the approach of Prusa and Sharp (2001), as well as the discussion in Durling and McCullough (2004). Similarly motivated regression-based approaches to the related framework of assessing the relationship between imports and injury in safeguards law can be found in Grossman (1986) and Pindyck and Rotemberg (1987).

46 Economists at the USITC have developed such a model, frequently referred to as the COMPAS model (Francois and Hall, 1993). For applying a similar approach to related injury and import causality linkage cases in safeguard cases, see also Kelly (1988) and Irwin (2003). 
when a more reliable though formal regression analysis is extremely difficult, perhaps because of lack of sufficiently disaggregated time series of data. This constraint is frequent when the scope of the investigation involves a few narrowly defined product categories and/or the period of investigation is a short time series.

The causal link in sunset reviews. In this section, we examine whether economist's arguments for the importance of a causal assessment, as well as the economic techniques to assess causality in anti-dumping investigations, more generally also apply to the case of likely dumping and likely injury determinations in sunset reviews.

The primary difference between the causation link in the injury-determination decision and one in a sunset review is that the latter is an assessment made prospectively. A sunset review decision is based on expectations of future circumstances relating two issues - the expected future pricing behavior of foreign firms and the expected future economic performance of the domestic industry in the presence of such expected foreign pricing behavior.

Because of the prospective nature of the assessment that is made in a sunset review, a regression-based analytical approach is not a useful exercise to assess the causality between any likely future dumping and any likely future injury. While the economic reasoning is quite intuitive, we do note that our arguments should not be misinterpreted as a statement condemning causation as a necessary component to anti-dumping more generally. It is simply that in the case of a sunset review, expected future market structure (e.g. number of competitors, degree of competition in the market, response of consumers) once the anti-dumping order is removed is an unknown, and this market structure is likely to be quite different from the market structure that exists empirically in the historical data that would be derived from a recent period during which an anti-dumping order was in place. Thus, even if a sufficiently disaggregated and long-time series of data were available (the usual constraint that can make even a desirable regression analysis impractical), drawing inference from such historical data derived from the period in which the order was in place is unlikely to accurately predict 'out of sample', future economic outcomes under conditions in which the anti-dumping order would not be in place. ${ }^{47}$

Would the alternative of an empirically based simulation approach be a useful exercise? Applying a simulation model could reveal useful insight as to the likelihood of future injury conditional on the likelihood of future dumping. Note, however, that use of such a model again requires information on a number of key parameters associated with expected future market outcomes - i.e., what would the demand, supply, and substitution elasticities 'look like' if the order were removed? Ultimately, an investigator would need to make an educated guess as to the size of these elasticities in a future state of the world and would therefore have

47 Indeed, this is one explanation for why Moore (2006) found little empirical relationship between traditional industry measures of injury (computed under the years of the order) and ITC sunset review injury decisions in the United States. 
to confront the question of whether market conditions have changed from the most 'comparable' state of the world. This is likely the state of the world prior to the anti-dumping order being in place.

This economic analysis ultimately leads us back to an analogy to the original sunset review insight provided by Howse and Staiger, here applied to this followup issue of injury and causality, i.e. that a meaningful assessment of the likelihood of continued or renewed injury caused by likely dumped imports requires an understanding of at least two things: (i) what were the causes of injury in the first place; and (ii) whether the conditions surrounding these factors have changed in a way that removes them as likely future causes of injury.

\section{Cumulation in sunset reviews}

Our second area of economic analysis addresses the question of an anti-dumping investigator's use of cumulated imports in the sunset review injury determination. The fundamental economic concern with the discretionary use of cumulation is that investigators may face the incentive to use it strategically in order to 'manipulate' decisions - e.g. finding evidence of likely continued or renewed injury when there would not otherwise be such evidence.

The basic economic problem with cumulation is that its presence creates the possibility that one exporter's decision has 'externality' implications on other firms in an anti-dumping investigation. Whenever an exporter does not face the full cost or benefit of the actions it takes, the result is that its decisionmaking leads to distortions and outcomes that are inefficient. In the presence of such externalities, economists have noted that it creates an incentive to 'free ride'. ${ }^{48}$

Howse and Staiger (2006) examine a related issue of economic incentives affected by free-riding in the context of an anti-dumping investigator being confronted with the choice of calculating dumping on a firm-specific basis versus an order-wide basis. They argue that if the likelihood of dumping depends importantly on factors that are under the control of specific companies (e.g. technology choices, input costs) as opposed to factors that are common across firms (e.g. exchange-rate movements) then the analysis should be done on the companyspecific basis. The intuition is that if margins are calculated order-wide, this can lead to free-riding behavior and ultimately inefficient outcomes. If a company's behavior affects the likelihood that its competitors will have an anti-dumping duty imposed or removed, then because the company does not face the full cost or benefit of its actions, it may decide to set prices or make other related choices that are inefficient. On the other hand, if the company knows that the decisions it makes only affect its own dumping margin (because the anti-dumping investigator has adopted a rule of calculating dumping on a firm-specific basis), all externalities are internalized, and there is no concern that this will lead to free-riding.

48 This assumes that the sunset review process would otherwise itself yield an efficient outcome. We do not address the broader possibility that the sunset review process itself is inefficient. 
The question of whether or not to allow for cumulation in an injury determination creates a similar set of economic concerns over free-riding. Just as exporters may change their pricing behavior away from what is individually optimal in recognition that such behavior will affect the dumping decisions that are being made with respect to their competitors (e.g. if using the 'order-wide' method), exporters may also change their behavior away from what is individually optimal if they anticipate that their actions influence the injury determinations facing their competitors (e.g. if a cumulation rule is allowed).

If cumulation is left at the discretion of investigators at the sunset review stage, government authorities with a particular 'bias' (for or against domestic industry) will make the decision of whether to cumulate strategically to influence their ex ante preferred outcome. One concern is that investigators will have an incentive to cumulate multiple countries into their likelihood of continued or renewed injury determination simply because this increases the probability of free-riding on the part of each individual investigated country. For example, such a decision to cumulate in a sunset review may increase the probability that each individual exporter underinvests in its legal defense to have the order removed, as it does not stand to capture the full benefit of its litigation efforts. Furthermore, the exporter's decision not to adequately defend itself is undertaken in anticipation of the ability to 'free ride' on other exporters' legal defense, since the injury determination is likely to be cumulated. But since all exporters face this underinvestment incentive, too little is cumulatively spent on the legal defense. The lack of an adequately funded legal defense may lead authorities to use the prejudicial 'best information available' (BIA) in their ultimate injury determination, and the result is that the order is more likely to remain in place.

This concern over free-riding and the cumulation rule in injury determinations in anti-dumping investigations is supported by the findings of economic research. Early research on US and EU anti-dumping investigations documented a curious and unexplained 'superadditivity' effect in cases in which investigators cumulated imports. The empirically documented superadditivity effect is that the probability of a positive injury finding is higher when the number of defendants in the case is larger, holding constant their total market share. ${ }^{49}$ Gupta and Panagariya (2006) provide a simple economic model to explain the empirically documented superadditivity effect. The Gupta and Panagariya explanation is that the larger is the number of exporters involved in the investigation, the smaller the incentive for each exporter to invest in its own defense, because there are positive externalities to them winning the case and not having a duty imposed. ${ }^{50}$ Thus, the incentive of

49 For evidence on US cases, see Hansen and Prusa (1996); for evidence of the impact of cumulation in EU cases, see Tharaka, Greenaway, and Tharakan (1998).

50 A complementary explanation that Gupta and Panagariya attribute to Robert Staiger at the end of their paper, is that cumulation may have a super-additive impact on injury findings if the probability of a positive finding rises with the size of the dumping margin. Specifically, their explanation is that '[c]eteris paribus, the larger the number of firms exporting to the country in which dumping takes place the more 
each exporter to 'free ride' leads to a smaller-than-optimal cumulative effort in putting up a legal defense, thus increasing the likelihood of a positive injury determination.

The economic intuition from cumulation, free-riding, and anti-dumping investigations extends to expected injury determinations in sunset reviews as well. Furthermore, exporters might not only have an incentive to free ride in sunset reviews, but certain exporters may have an incentive to try and (perversely) increase the probability of a continued or renewed likelihood of injury in the presence of cumulation, so that an anti-dumping order remains in place across numerous foreign competitors.

As one example to see the incentives behind this phenomenon, suppose that during the lengthy period that the anti-dumping order had been in effect, a firm that was originally simply an exporter had established a subsidiary within the investigating market, e.g. what is referred to as 'anti-dumping-jumping' foreign direct investment (FDI). Blonigen and Ohno (1998) present a model where the possibility of anti-dumping-jumping FDI creates incentives for foreign firms to act strategically vis-à-vis their other foreign competitors (e.g. increase dumping, causing injury) in anticipation of being able to subvert the antidumping order by becoming a 'domestic' producer through FDI. Because of cumulation, their actions will adversely affect other exporters, and the possibility of the FDI alternative also means that they will experience less of a consequence of their strategic actions if in the future much of their sales stem from local subsidiaries.

Furthermore, a second example could arise even without the need for FDI simply because of the discriminatory nature of the anti-dumping orders imposed. An important factor affecting an individual exporter's behavioral decision is the relative levels of anti-dumping orders that have been imposed. If an exporter's primary competition comes from other exporting firms, there are other potential scenarios in which even an exporter under an anti-dumping order may prefer the status quo of continued orders for all exporters relative to having all anti-dumping orders removed, as would be the case in a successful sunset review. Suppose the exporter has an extremely low margin, relative to the other foreign competitors, and that the domestic industry is either capacity-constrained or perhaps has even exited the market since the original order was imposed.

The overall implication is that even in sunset reviews, the cumulation rule allows for one firm's decisions to have substantial externality implications for other firms. This, in turn, leads to inefficient outcomes. A way to eliminate this inefficiency is to have firms internalize the implications of their decision, an outcome that is 
more likely if anti-dumping investigators are not allowed to cumulate imports in expected injury sunset review determinations.

Do sunset reviews matter?

In this section, we provide a brief economic comment on the question of whether sunset reviews matter for the duration of imposed anti-dumping measures. Cadot, de Melo, and Tumurchudur (2007) empirically investigate a number of questions relating to sunset reviews. One of their results is that the change that has mandated sunset reviews during the WTO period has led to a stronger five-year cycle for the duration of anti-dumping measures, relative to the GATT period, during which there was no mandatory sunset review process.

Nevertheless, the authors present findings that there is still substantial heterogeneity in the duration of imposed anti-dumping measures across countries. For example, they find that the United States seems to have failed to comply with the spirit of the sunset review process, as it has continued to extend the duration of imposed anti-dumping measures beyond the five-year initial period. For a number of other countries, they find a higher likelihood of terminating measures after a sunset review at the five-year point. Nevertheless, even for these countries, the apparent evidence is that this action is undertaken 'voluntarily', i.e. it is not necessarily caused by the sunset review provisions of the ADA. ${ }^{51}$ The implication is that such countries might have done so anyway, even if it were not mandated by the WTO agreements - thus, it is still an open question as to whether the mandatory sunset reviews have had an effect on the duration of imposed anti-dumping measures.

\section{Conclusion}

Two conclusions can be drawn from this case: First, the AD Agreement, as interpreted by the Appellate Body in this and other similar cases, imposes only minimal disciplines of a general nature on Members wishing to extend the anti-dumping measure beyond its original five-year period. This is problematic, as it seems to void much practical meaning from the rule that says that anti-dumping measures are to be terminated after five years. The very deferential approach towards sunset reviews taken by the Appellate Body is difficult to reconcile with its own statement that termination of a measure is the rule, and continuation the exception. That is certainly not true in the US. Yet, for 'textual' reasons, the Appellate Body has rejected almost all claims against the US laws and regulations that provide the framework for the US approach. As we tried to demonstrate in this paper, this 'textual' argument is weak and has resulted in undermining the practical effect of, what was considered to be, one of the major achievements of the Uruguay Round

51 This analysis is based on evidence that there seems to be little difference in how WTO members treat antidumping targets that are other WTO members (treatment group) versus targets that are WTO nonmembers (control group) in sunset reviews. 
Anti-Dumping Agreement: limiting the life span of an anti-dumping measure to five years.

Second, from an economic perspective, it seems that Panels and the Appellate Body are simply debating the wrong type of questions. The prospective nature of the analysis that is to be performed in a sunset review raises particular questions in terms of the data to be used; it requires an overall approach that is different from the approach in an original investigation, which is retrospective in nature. Questions such as why exporters engaged in dumping in the first place, and what the conditions of the industry were so that the dumped imports were able to cause injury in the first place are important questions that are not answered in an original investigation. The answers to these questions are important however, as they could form the basis for a more meaningful prospective sunset analysis. At the moment, sunset reviews seem adrift as Panels and the Appellate Body fail to give guidance to Members on how to do a more economically sound and informed review. Unfortunately, this problem is not unique to sunset reviews, but is an inherent problem of the $\mathrm{AD}$ Agreement, and the use of anti-dumping as a trade policy instrument more generally.

\section{References}

Blonigen, Bruce A. and Yuka Ohno (1998), 'Endogenous Protection, Foreign Direct Investment, and Protection-Building Trade', Journal of International Economics, 46: 205-227.

Blonigen, Bruce A. and Jee-Hyeong Park (2004), 'Dynamic Pricing in the Presence of Anti-dumping Policy: Theory and Evidence’, American Economic Review, 94: 134-154.

Cadot, Olivier, Jaime de Melo, and Bolormaa Tumurchudur (2007), 'Anti-Dumping Sunset Reviews: The Uneven Reach of WTO Disciplines', University of Geneva manuscript, February.

Durling, James P. and Matthew P. McCullough (2004), 'Teaching Old Laws New Tricks: The Legal Obligation of Non-Attribution and the Need for Economic Rigor in Injury Analyses under US Trade Law', in James Hartigan and E. Kwan Choi (eds), Handbook of International Trade, Vol. II, New York: Blackwell.

Francois, Joseph and Keith Hall (1993), 'COMPAS: Commercial Policy Analysis System', US International Trade Commission, May.

Grossman, Gene M. (1986), 'Imports as a Cause of Injury: The Case of the US Steel Industry', Journal of International Economics, 20: 201-223.

Gupta, Poonam and Arvind Panagariya (2006), 'Injury Investigations in Antidumping and the SuperAdditivity Effect: A Theoretical Explanation', Weltwirtschaftliches Archiv/Review of World Economics, 142: 151-164.

Hansen, Wendy L. and Thomas J. Prusa (1996), 'Cumulation and ITC Decision-Making: The Sum of the Parts is Greater Than the Whole', Economic Inquiry, 34: 746-769.

Howse, Robert and Robert W. Staiger (2006), 'United States - Sunset Review of Anti-Dumping Duties on Corrosion-Resistant Carbon Steel Flat Products From Japan: A Legal and Economic Analysis of the Appellate Body Ruling', in Petros C. Mavroidis and Henrik Horn (eds), The WTO Case Law of 2003, Cambridge: Cambridge University Press.

Irwin, Douglas A. (2003), 'Causing Problems? The WTO Review of Causation and Injury Attribution in US Section 201 Cases', World Trade Review, 2: 297-325.

Kelly, Kenneth (1988), 'The Analysis of Causality in Escape Clause Cases', The Journal of Industrial Economics, 37: 187-207. 
Moore, Michael O. (2006), 'An Econometric Analysis of US Antidumping Sunset Review Decisions', Weltwirtschaftliches Archiv/Review of World Economics, 142: 122-150.

Pindyck, Robert S. and Julio J. Rotemberg (1987), 'Are Imports to Blame? Attribution of Injury under the 1974 Trade Act', Journal of Law and Economics, 30: 101-122.

Prusa, Thomas J. and David C. Sharp (2001), 'Simultaneous Equations in Antidumping Investigations', Journal of Forensic Economics, 14: 63-78.

Tharakan, P. K. M., D. Greenaway, and J. Tharakan (1998), 'Cumulation and Injury Determination of the European Community in Antidumping Cases', Weltwirtschaftliches Archiv/Review of World Economics, 134: 320-339. 